\title{
THE HORSECHESNUT LEAFMINING MOTH (CAMERARIA OHRIDELLA): A NEW PEST IN CENTRAL EUROPE
}

\author{
by Christian Tomiczek ${ }^{1}$ and Hannes Krehan ${ }^{2}$
}

\begin{abstract}
The horsechestnut (Aesculus hippocastanum) is one of the most popular shade trees in central Europe. Although it was introduced only 400 years ago from southeast Europe, at least 20,000 horsechestnuts grow in Vienna and its environs. The horsechestnut was a tree species with few health problems (e.g., Guignardia aesculi Ascomycetes) until the leafminer Cameraria ohridella was imported-first to Macedonia and later on to central Europe. The origin, biology, damage, population dynamics, natural limitation factors, economic impact, management options, and control of $C$. ohridella are discussed.
\end{abstract}

In 1984, severe damage to Aesculus hippocastanum by an unknown leafminer near Lake Ohrid in Macedonia was reported (Simova-Tosic and Filev 1985); the leafminer was later described as Cameraria ohridella (Lepidoptera, Lithocolletidae) (Figure 1) (Deschka and Dimic 1986). In 1989, only 5 years later, the leafminer was recorded some $1,000 \mathrm{~km}(620 \mathrm{mi})$ north in central Austria (Puchberger 1995) and also in Zagreb, Croatia (Maceljski and Berti'c 1992). By 1992, mass outbreaks of the horsechestnut leafminer were observed near the introduction area. Since then, the pest has spread throughout Austria

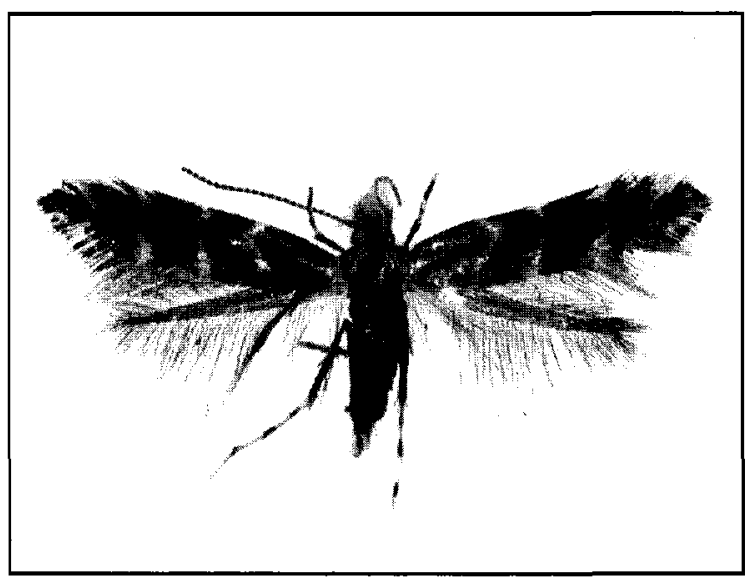

Figure 1. Cameraria ohridella moth. and reached Hungary (Szabóky 1997), Germany (Butin and Führer 1994), and the Czech Republic in 1993 (Liska 1997) and Slovakia (Sivicek et al. 1997) in 1994 (Figure 2).

\section{Origin}

It is still quite unclear where the leafminer originated. Davis (in Pschorn-Walcher 1997) concluded that $C$. ohridella is quite different from all known American Cameraria species. Therefore, the horsechestnut leafmining moth probably is a southeastern European relict species of Cameraria (Pschorn-Walcher 1994). However, because $C$. ohridella is a monophagous insect species, practically all natural Aesculus stands (worldwide, 16 species of Aesculus are known) could be the origins. Deschka (1993) mentioned 13 different plants susceptible to Cameraria.

\section{Biology and Damage by Cameraria ohridella} The flight period of the moth and oviposition begin in the warmer parts of Austria during the end of April and early May, depending on weather conditions. The eggs are laid individually on the upper surface of Aesculus leaves, usually between leaf veins. Two to three weeks later, the first small, comma-shaped mines can be observed (Figure 3). The larvae and mines grow steadily for 4 to 5 weeks, resulting in light brown mines 3 to $4 \mathrm{~cm}$ ( 1.2 to $1.6 \mathrm{in}$.) long. The caterpillars pupate and emerge 2 to 3 weeks later; this generation lasts 7 to 10 weeks. In warmer climatic regions with optimal weather conditions, up to 3 generations per year are possible. The 3rd generation usually overwinters in the pupal stage on the ground in the litter layer. Young larvae live within the palisade parenchyma and feed on sap, whereas the older larvae (3rd stage) mine between leaf veins. 


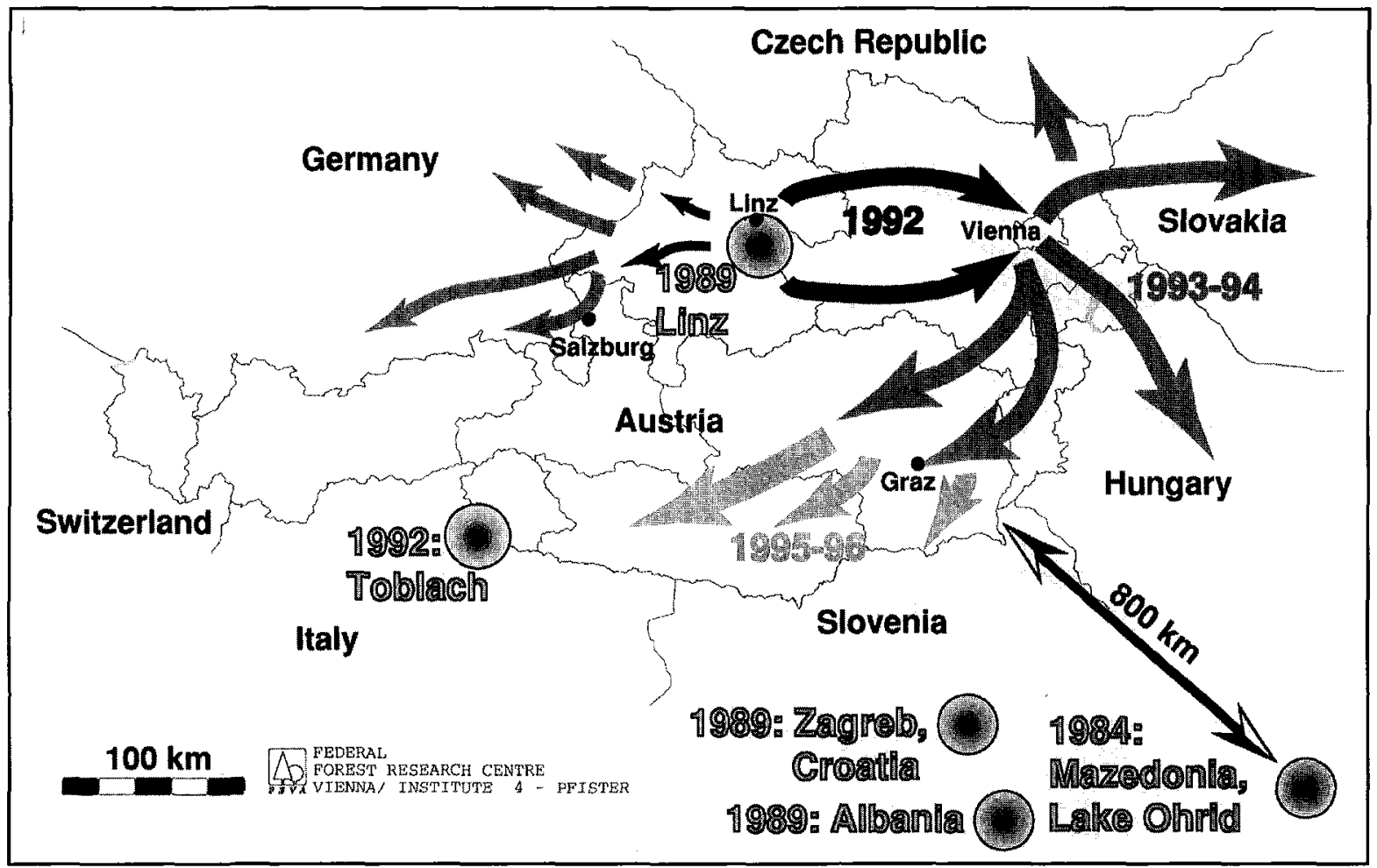

Figure 2. Spread of C. ohridella in central Europe, 1984 to 1997.

The main damage is caused by larvae feeding on Aesculus hippocastanum leaves (Figure 4). Much less extensive feeding is seen on the leaves of the red flowering hybrid of the horsechestnut tree (Aesculus carnea $=$ hybrid of $A$. pavia and $A$. hippocastanum). As a result of mining, the leaves start yellowing and browning by the end of June. Up to 200 mines per horsechestnut leaf can be counted. The 1st generation of $C$. ohridella feeds mainly in the lower parts of the crown, while the 2nd generation feeds predominantly in the upper crown. When damage is heavy, leaf-fall may occur by the end of July, with no remaining leaves suitable for oviposition. In some cases, the horsechestnut flowers again in September, with young leaves appearing. Consequently, no 3rd generation of c. ohridella appears. On occasion, Acer pseudoplatanus is attacked by $C$. ohridella when no Aesculus leaves are present (Krehan 1995) (Figure 5). Until now, complete development of C. ohridella (from egg to emerging moth) on maple has not been observed.

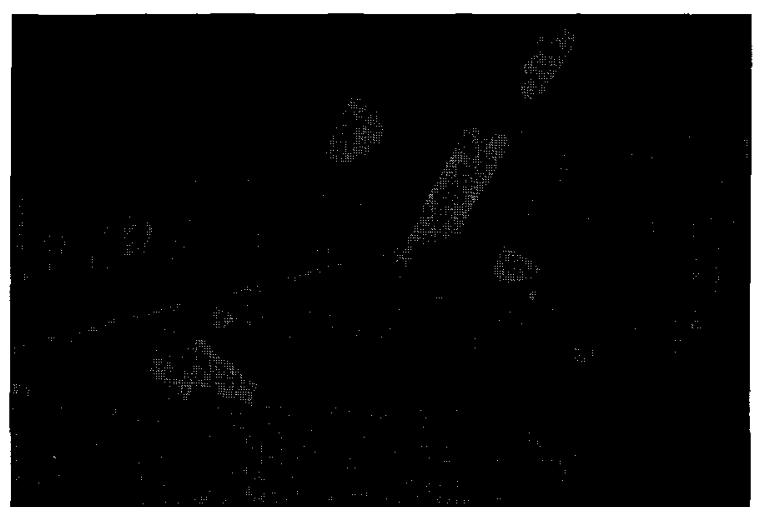

Figure 3. Initial stage of damage by C. ohridella (1st generation).

Population dynamics. In 1996, more than $250,000 \mathrm{~km}^{2}\left(9,600 \mathrm{mi}^{2}\right)$ were damaged by the moth in central Europe, and the infestation area is growing steadily. Areal expansion occurs most rapidly in an eastern direction.

Natural limitation factors. Currently, the most important natural mortality factor is intraspecific competition of the larvae for space and food within 


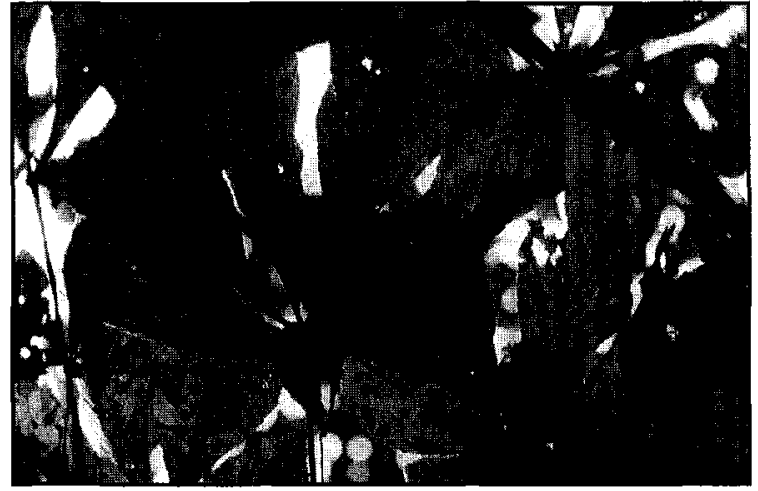

Figure 4. Leaf mines of $C$. ohridella on Aesculus hippocastanum.

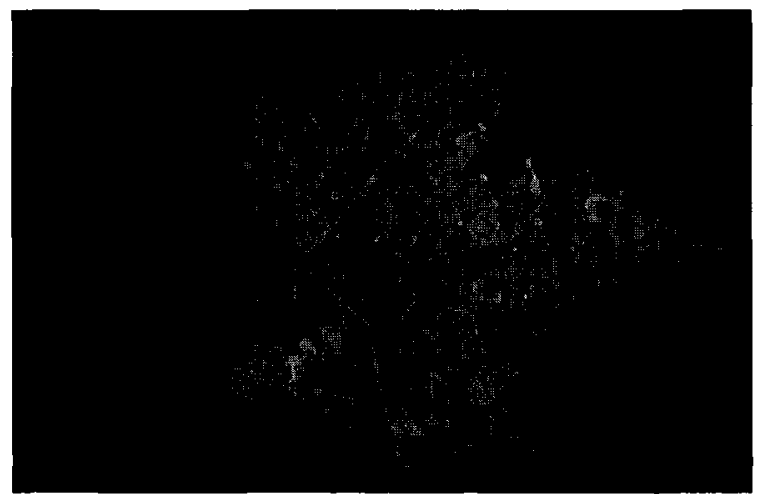

Figure 5. Leaf mines of $C$. ohridella on Acer pseudoplatanus.

leaves. Initial investigations on parasitism in $C$. ohridella showed a low incidence of parasitism in Europe (Deschka and Dimic 1986; Krehan 1995; Stolz 1997). Unfavorable weather conditions may delay maturation of eggs, but the mortality rate among feeding larvae is very low (between $3 \%$ and $55 \%$ in the 2nd and 3rd generations [Table 1]). Because cocoons reside inside fallen leaves, the overwintering pupa are well protected against winter desiccation.

Economic impact. Horsechestnuts are very important shade trees in Europe. Therefore, arborists intensively strive to keep the trees healthy and free from pests. There is concern that most of the Aesculus hippocastanum trees will decline because of heavy and long-lasting attacks of $C$. ohridella. Fortunately no horsechestnut tree has died from the 3 or 4 years of infestation by Cameraria larvae. Nevertheless, the early loss
Table 1. Mortality and parasitism rate of C. ohridella larvae (counted in August and September 1997, out of about 150 to 400 leaf mines per tree).

\begin{tabular}{lrc}
\hline & $\begin{array}{r}\text { Mortality } \\
\text { rate }(\%)\end{array}$ & $\begin{array}{c}\text { Parasitism } \\
\text { rate (\%) }\end{array}$ \\
\hline B.1 (Vienna west A) & 28.35 & 9.80 \\
B.2 (Vienna west B) & 3.35 & 1.68 \\
B.3 (Vienna west C) & 16.67 & 3.21 \\
B.4 (Vienna west D) & 7.41 & 2.47 \\
B.5 (Vienna west E) & 3.88 & 1.70 \\
B.6 (Vienna Prater) & 18.18 & 10.39 \\
B.7 (Vienna Center) & 32.90 & 15.20 \\
B.8 (Kirchstetten NÖ) & 55.00 & 15.20 \\
B.9 (Lainzer Game Park) & 25.20 & 0 \\
\hline
\end{tabular}

of the leaves will deplete starch reserves and increase the predisposition to other harmful environmental influences and diseases.

\section{Management Options and Control}

Because $C$. ohridella overwinter in the pupal stage in fallen leaves and litter, removal and composting of dead leaves is a common practice for control. Field observations in Vienna showed that these measures decrease the spring population of the moths (Marx 1997). Suppression of the larval stage of the pest is achieved by spraying chitin synthesis inhibitors (e.g., Dimilin [diflubenzuron] $0.04 \%$ a.i. or Alsystin [triflumuron] $0.04 \%$ a.i.) (Blümel and Hausdorf 1997; Krehan 1997). Application should be made immediately before or during oviposition, as has been demonstrated with other leafmining insects (Marion et al. 1990). Topical sprays should not be applied when the larvae have already begun to form mines inside the leaves because Dimilin and Alsystin have no systemic effect and cannot control the internal larvae. Because of the persistence of these compound, 1 application per year is sufficient.

Initial experiments with tree infusions using new systemic insecticides (acetamiprid and imidacloprid) showed good control results when the insecticide is transported by the vessels of the tree to all parts of the crown in correct quantity and concentration. If the dosage is too high, leaves show wilting symptoms, especially on the upper position of the crown where the translocation of the insecticides ismost intensive. Field trials with Acecap implants (Orthene) had no success with control of Cameraria (Krehan 1997). 
Unfortunately, cultural practices are expensive and not as efficient as synthetic insecticides, and chemical applications are not popular. Furthermore, cultural control methods provide only temporary solutions. Classic biological control, by importation of specific natural enemies from the region of origin of the pest, should be addressed in future control regimens.

The most important natural leafminer enemies are parasitoides. On average, leafminers support more parasitoides and suffer more parasitism than any other insect group (Hawkins 1994). The low rate of parasitism of $C$. ohridella in central Europe and in Macedonia indicates that the leafmining moth possibly originates from another part of the world. In its region of origin, it is most likely controlled by a complex of parasitoides and therefore never develops into outbreaks. Classic biological control seeks to select important regulatory natural enemies within this complex and to introduce these species through a strict quarantine procedure. Once introduced and implemented, the natural enemy provides lasting control of the pest with only occasional need for intervention. Many precedents exist for the successiul biological control of exotic leafminers (Argov and Rössler 1996; Kenis 1997).

\section{Conclusion}

The horsechestnut leafmining (Cameraria ohridel/a) moth has been introduced to Macedonia and central Europe in recent years. It is unclear where the insect originates. $C$. ohridella is a monophagous insect that damages only Aesculus hippocastanum. Feeding by larvae induces leaf discoloration and early leaf-fall in July or August. Application of Dimilin or similar chemicals immediately before oviposition achieves good control results, but classic biological control by importation of natural enemies should be incorporated in the future.

\section{Literature Cited}

Argov, Y., and Y. Rössler. 1996. Introduction, release and recovery of several exotic natural enemies for biological control of the citrus leaf miner Phyllocnistis citrella, in Israel. Phytoparasitica. 24:33-38.
Blümel, S., and H. Hausdorf. 1997. Versuche zur Kontrolle von Cameraria ohridella Deschka \& Dimic mit insektiziden Wachstumsregulatoren. Forstschutz-Aktuell, Wien. 21:16-18.

Butin, H., and E. Führer. 1994. Die KastanienMiniermotte (Cameraria ohridella Deschka \& Dimic), ein neuer Schädling an Aesculus hippocastanum. Nachrichtenbl. Deut. Pflanzenschutzdienst. 46(5):89-91.

Deschka, G. 1993. Die Miniermotte Cameraria ohridella Deschka \& Dimic eine Gefahr für die Roßkastanie Aesculus hippocastanum L. (Insecta, Lepidoptera, Lithocolletidae). Linzer biol. Beiträge. 25/1:141-148.

Deschka, G., and N. Dimic. 1986. Cameraria ohridella n.sp. aus Mazedonien, Jugoslawien (Lepidoptera, Lithocolletidae). Acta Entom. Jugosl. 22:11-23.

Hawkins, B.A. 1994. Pattern and Process in HostParasitoid Interactions. Cambridge University Press. 190 pp.

Kenis, M. 1997. Möglichkeiten einer biologischen Kontrolle von Cameraria ohridella mit eingeführten natürlichen Feinden. Forstschutz-Aktuell, Wien. 21:27-29.

Krehan, H. 1995. RoßkastanienminiermotteBefallssituation in Österreich. Forstschutz-Aktuell, Wien. 16:8-11.

Krehan, H. 1997. Stadtbaum-Aktuell: Roßkastanienminiermotte-Vergleich der Bekämpfungsverfahren. Forstschutz-Aktuell, Wien. 19/20:1-6.

Liska, J. 1997. Verbreitung der Roßkastanienminiermotte in Tschechien. Forstschutz-Aktuell, Wien. 21:5.

Maceljski, M., and Berti'c. D. 1997(?). Kestenov moljac miner-Cameraria ohridella Deschka \& Dimi'c (Lep. Lithocolletidae)- novi opasni stetnik $u$ hrvatskoj. Fragmenta Phytomedica et Herbologica (1995) 23(2):9-18.

Marion, D.F., Larew, H.B., Knodei, J.J., and Natoli, W. 1990. Systemic activity of Neem extract against birch leaf miner. J. Aboric. 16(1):12-16.

Marx, F. 1997. Maßnahmen gegen die Kastanienminiermotte (Cameraria ohridella) aus der Praxis des Stadtgartenamtes der Gemeinde Wien. Forstschutz-Aktuell, Wien. 21:21-22.

Pschorn-Walcher, H. 1994. Freilandbiologie der eingeschleppten Roßkastanien-Miniermotte Cameraria ohridella Deschka \& Dimic (Lep., Gracillariidae) im Wienerwald. Linzer biol. Beiträge. 26(2):633-642.

Pschorn-Walcher, H. 1997. Zur Biologie und Populationsentwicklung der eingeschleppten 
Roßkastanien-Miniermotte, Cameraria ohridella. Forstschutz-Aktuell, Wien. 21:7-10.

Puchberger, K.M. 1995. Zur Geschichte der ersten Ausbreitung von Cameraria ohridella Deschka \& Dimic 1986 in Österreich (Lepidoptera, Gracillariidae). Ent. Nachr.Blatt, Wien. 2 (1):2-3.

Simova-Tosic, D., and S. Filev. 1985. Contribution to the horsechestnut miner (in Serbocroatia). Zastíta bílja, Belgrade. 36:235-239.

Sivicek, P., P. Hrubik, and G. Juhásová. 1997. Verbreitung der Roßkastanienminiermotte in der Slovakei. Forstschutz-Aktuell, Wien. 21:6.

Stolz, M. 1997. Untersuchungen über Larval- und Puppenparasitoide von Cameraria ohridella in Hinblick auf ihre Eignung zur Laborzucht. Forstschutz-Aktuell, Wien. 21:30-31.

Szabóky, C. 1997. Verbreitung der RoBkastanienminiermotte in Ungarn. ForstschutzAktuell, Wien. 21:4.

\section{${ }^{1}$ Tree Pathologist \\ Institute of Forest Protection \\ Federal Forest Research Centre \\ A-1131 Vienna, Austria}

\section{${ }^{2}$ Forest Entomologist \\ Institute of Forest Protection \\ Federal Forest Research Centre \\ A-1131 Vienna, Austria}

Résumé. Le marronnier d'Inde (Aesculus hippocastanum), introduit en Europe, était une espèce avec peu de problèmes jusqu'à ce que la mineuse Cameraria ohridella soit importée d'abord en Macédoine, puis en Europe Centrale. On y discute de l'origine, de la biologie, des dommages, de la dynamique des populations, des facteurs naturels limitatifs, de l'impact économique, et des différentes options de gestion et de contrôle de $C$. ohridella. De sévères dommages ont été rapportés en 1985 sur l'A. hippocastanum par une mineuse inconnue près du lac de l'Orchidée en Macédoine. Seulement trois ans plus tard (1989), la mineuse était rapportée à $1500 \mathrm{~km}$ plus au nord en Autriche Centrale. Durant la période 1990-'91, de fortes éclosions de mineuses du marronnier ont pu être observées près de la zone d'introduction. Depuis ce temps, l'insecte parasite s'est répandu au travers de l'Autriche, a atteint la Hongrie et la République tchèque en 1993, la Slovaquie en 1994 et enfin l'Allemagne en 1996.

Zusammenfassung. Die Roßkastanienminiermotte (Cameraria ohridella) wurde zuerst nach Mazedonien und später nach Österreich und in die angrenzenden Nachbarländer verschleppt. Bis heute ist das tatsächliche Ursprungsgebiet des Insekts unklar. $C$. ohridella lebt monophag und schädigt ausschließlich Aesculus hippocastanum. Der Larvenminierfraß führt zu Blattverfärbung und vorzeitigem Laubfall im Juli oder August. Sprühen mit Dimilin oder ähnlichen Chemikalien unmittelbar vor der Eiablage zeigt guten Bekämpfungserfolg, doch sollte die klassische biologische Bekämpfung mittels Einfuhr natürlicher Feinde aus dem Ursprungsgebiet der Motte, in Zukunft forciert werden.

Resumen. El castaño-caballar (Aesculus hippocastanum), introducido a Europa, era una especie arbórea con pocos problemas de salud hasta que el minador de la hoja Cameraria ohridella fue importado primero a Macedonia y más tarde a Europa Central. Se discute el origen, biología, daños, dinámica de las poblaciones, factores limitantes naturales, impacto económico, opciones de control y manejo de $C$. ohridella. En 1985 fueron reportados severos daños a A.hippocastanum por un minador desconocido, cerca al lago Orquídea en Macedonia. Solamente 3 años más tarde (1989) el minador fue registrado a unos $1,500 \mathrm{~km}$ al norte en Austria Central. En 1990/91 fueron observados ataques en masa del minador de la hoja del castaño-caballar cerca al área de introducción. Desde entonces la plaga se ha propagado a través de Austria, llegando a Hungria y la República Checa en 1993, Eslovaquia en 1994 y Alemania en 1996. 